\title{
New 1,2,4-triazine bearing compounds: molecular modeling, synthesis and biotesting
}

\author{
L. G. Palchykovska, I. V. Alexeeva, M. O. Platonov, O. M Kostenko, L. S. Usenko, \\ V. V. Negrutska, A. D. Shved
}

Institute of molecular biology and genetics NAS of Ukraine

150, Zabolotnogo Str, Kyiv Ukraine, 03680

1.palchykovska@imbg.org.ua

\begin{abstract}
Aim. To enlarge a spectrum of biologically active compounds in the series of the 1,2,4-triazino[5,6-b] [1,4]benzothiazine (1,2,4-TBT) derivatives and reveal among them efficient inhibitors of RNA synthesis Methods. The methods of structure optimization of the 3-oxo-1,2,4-TBT by fragment-oriented substitution, the molecular doking of new structures in a virtual target, the rational chemical synthesis of the theoretically predicted compounds and their testing in the system of transcription in vitro. Results. The series of 1,2,4-TBT derivatives with substituents in the benzene and triazine cycles of a base molecule were synthesized. The testing of synthesized compounds in the in vitro transcription system directed by T7 RNA polymerase revealed the structure- and concen-tration-dependent inhibition of the RNA synthesis by some of these compounds. The experimental and virtual screening data for all investigated compounds have a good correlation. It was found that most effective derivative is the 3-oxo-8-butyl-1,2,4-TBT which completely inhibited transcription at the concentration of $6 \mathrm{mg} / \mathrm{ml}$. Conclusions. The biotesting results allow us to assume that the inhibition of RNA synthesis is caused by binding of the 3-oxo-8-butyl-1,2,4-TBT to both free RNA polymerase molecules and tho- se including in a transcriptional complex with DNA.
\end{abstract}

Keywords: 1,2,4-triazino[5,6-b][1,4]benzothiazines, design, virtual screening, synthesis, model transcription system.

Introduction. Biological effect of polycyclic planar molecules is commonly ascribed to their interaction with DNA [1]. The compounds of such nature may inhibit the function of enzyme complexes in the system of nucleic acid biosynthesis involving DNA, such as RNA- and DNA-polymerase, -topoisomerase,

(C) Institute of Molecular Biology and Genetics NAS of Ukraine, 2009 -helicase complexes, etc. Preliminary studies on the effect of a number of new tricyclic 1,2,4-triazine-bearing bases and their nucleosides on reproduction of viruses from Herpes viridae family, virus of common herpes ( $\mathrm{VCH})$ and Epstein-Barr virus (EBV) [3, 4] prompted us for further optimization of the parent base to obtain more effective antiviral substances. 
The aim of this work is to extend the spectrum of effective biologically active compounds of tricyclic system, 1,2,4-triazino[5,6-b][1,4]-benzothiazines $(1,2,4-\mathrm{TBT})$, bioisosters of the alloxazine and isoalloxazine (that present natural components of riboflavin coenzymes), and structural analogs of some polycyclic antibiotics. Given the possibility of viral polymerase inhibition it seemed reasonable to estimate the effect of new derivatives on the RNA synthesis in model system of transcription directed by DNA-dependent T7 RNA-polymerase (RNAP) in vitro.

To achieve the desired aim it was necessary to tackle such problems: to perform computer design of starting compound, 3-oxo-1,2,4-TBT, through modifying triazine and benzothiazine fragments of the molecule and clear up the putative mechanism of action for the designed new structures by their molecular docking to virtual target of the T7 RNAP catalytic site.

Materials and methods All calculations were performed in program QXP /Flo+ [8]. Docking was carried out using flexible ligand and fixed models of the receptor to employ the algorithm of systematic docking $(\mathrm{SDOCK}+)$, which demonstrated satisfactory ability to reproduce ligand conformation with minimal RMSD (medium square deviation) relative to crystallographic results [9]. Maximal number of calculation steps was determined on 300 and 10 optimal complexes (proceeding from inherent scoring functions of QXP) that are maintained for [the] analysis. The receptor model was based on X-ray results for T7 RNAP-DNA (PDB X-Ray code: 1SOV) transcription complex [10].

Chemical synthesis. For the synthesis of condensed triazine derivatives 6-bromo-1,2,4-triazin-3,5(2H,4H)dione (1), its 2- $\beta$-D-triacetylribofuranoside (2) and 2-amino-4(5)-R-benzothiols (3) were used, synthesized according to described earlier techniques [11, 12]. Other reagents and solvents were purchased from UkrOrgSynthesis (Ukraine) and "Fluka" (Switzerland).

The obtained compounds were controlled through thin layer chromatography (TLC) on the plates Silica gel 60 F254 («Merck», Germany) in the system of chloroform/ethanol (9:1) or (98:2) solvents. For preparative chromatography on silica gel a gradient of ethanol concentrations in chloroform was used. ${ }^{1} \mathrm{H}-\mathrm{NMR}$ spectra of synthesized compounds were recorded on spectrometer «Mercury-400» («Varian», USA) in DMSO-d6, electronic absorption spectra - on spectrometer Shimadzu UV-3100 (Japan). Melting points (mp) were estimated on Boetius device.

General technique for production of 2,4-dihydro-3-oxo-7(8)-R-1,2,4-triazino[5,6-b][1,4]b enzothiazines (4a-c). 5-mMol triazine bromoderivative (1) and $5 \mathrm{mmol}$ respective 2-aminobenzothiol (3) were boiled in $10 \mathrm{ml}$ of dioxane-pyridine mixture (9:1) with backflow condenser for $4 \mathrm{~h}$. The first hour reaction results in voluminous precipitate which is gradually dissolved during its further occurrence. Following the reaction mixture cooling, the solvents were removed in vacuum, to crystallize the residue with N,N-dimethylformamide (physico-chemical characteristics of the novel compounds are presented in the table).

Synthesis of 2- $\beta$-D-ribofuranosyl-3(4H)-oxo7-trifluoromethyl-1,2,4-triazino[5,6-b][1,4]benzothia zine (5a). Me th o d I. Suspension of acylnucleoside $\mathbf{2}$ bromoderivative (452 $\mathrm{mg}, 1 \mathrm{mmol}$ ) in $5 \mathrm{ml}$ [of] ethanol:dimethylformamide (4:1) mixture was added by $0.08 \mathrm{ml}$ [of] pyridine $(1 \mathrm{mmol})$ and 2-amino-4-trifluoromethyl-benzothiol (3a) (0.193 g, 1 $\mathrm{mmol}$ ) and boiled for $8 \mathrm{~h}$. After solvent evaporating, acylnucleoside was isolated by chromatography on column with Silica gel followed by subsequent deblocking with $25 \%$ hydroxide ammonium solution $(10 \mathrm{ml})$ for $20 \mathrm{~h}$ at room temperature. Target ribonucleoside was crystallized with ethanol. $112 \mathrm{mg}$ $(27 \%)$ of analytically pure $\mathbf{5 a}$ were produced.

Me th od II. To a suspension of base 4 a $(290 \mathrm{mg}$, $1 \mathrm{mmol}$ ) and tetraacetylribose $(350 \mathrm{mg}, 1.1 \mathrm{mmol})$ in $10 \mathrm{ml}$ of anhydrous acetonitrile was added $0,2 \mathrm{ml}(1,6$ $\mathrm{mmol})$ of trimethylclorosilane (TMCS), $0,17 \mathrm{ml}(0,8$ mmol) [of] hexamethyldisilane (HMDS) and $0.15 \mathrm{ml}$ $(1,6 \mathrm{mmol})$ [of] tin tetrachloride. The reaction mixture was stirred for $7 \mathrm{~h}$ at room temperature and evaporated to dryness in vacuum. The residue was dissolved in chloroform, washed with water and solution sodium acetate, dried over magnesium sulfate, filtered and evaporated to a dark syrup. The acylnucleoside [was] purified by flash chromatography on silica gel by subsequent removal of acetylic groups with hydroxide ammonium solution. The crystalline nucleoside 5a was obtained: yield $138 \mathrm{mg}$ (33\%). 
Physico-chemical characteristics of the synthesized 1,2,4-triazino[5,6-b][1,4]benzothiazine derivatives (4a-c, 5a, 5b)

\begin{tabular}{|c|c|c|c|c|}
\hline Compound & Yield, \% & M.p., $\left({ }^{\circ} \mathrm{C}\right)$ & ${ }^{1} \mathrm{H}-\mathrm{NMR}\left(\mathrm{DMSO}-\mathrm{d}_{6}: \delta(\mathrm{ppm})\right.$ & $\mathrm{UV}, \lambda_{\max }, \mathrm{nm}$ \\
\hline $4 a$ & 67 & $\geq 300$ & $\begin{array}{c}\text { 7,03 (m, 2H, Ph); 7,17 (d, 1H, Ph ); 11,27 (s, 1H, NH); } \\
12,09 \text { (br. s, 1H, NH) }\end{array}$ & $232 ; 246 ;[280] * ; 369$ \\
\hline $4 b$ & 80 & 330 & $\begin{array}{c}7,26(\mathrm{~s}, 1 \mathrm{H}, \mathrm{Ph}) ; 7,34(\mathrm{~d}, 1 \mathrm{H}, \mathrm{Ph}) ; 7,26(\mathrm{~s}, 1 \mathrm{H}, \mathrm{Ph}) ; 11,25(\mathrm{~s} \\
1 \mathrm{H}, \mathrm{NH}) ; 12,15(\mathrm{~s}, 1 \mathrm{H}, \mathrm{NH})\end{array}$ & $212 ; 243 ;[268]^{*} ; 379$ \\
\hline $5 \mathbf{a}$ & $27(33)^{* *}$ & $165-167$ & $\begin{array}{c}3,41\left(\mathrm{~m}, 1 \mathrm{H}, \mathrm{H}_{\beta^{-}} 5^{\prime}\right) ; 3,50\left(\mathrm{~m}, 1 \mathrm{H}, \mathrm{H}_{\alpha}-5^{\prime}\right) ; 3,78\left(\mathrm{~d}, 1 \mathrm{H}, \mathrm{H}-4^{\prime}\right. \\
\mathrm{J}=4,8) ; 3,98\left(\mathrm{dd}, 1 \mathrm{H}, \mathrm{H}-3^{\prime}\right) ; 4,15\left(\mathrm{dd}, 1 \mathrm{H}, \mathrm{H}-2^{\prime}\right) ; 4,39(\mathrm{t} \\
\left.1 \mathrm{H}, \mathrm{OH}-5^{\prime}\right) ; 4,79\left(\mathrm{~d}, 1 \mathrm{H}, \mathrm{OH}-3^{\prime}, \mathrm{J}=5,6\right) ; 5,00(\mathrm{~d}, 1 \mathrm{H} \\
\left.\mathrm{OH}-2^{\prime}, \mathrm{J}=4,8\right) ; 5,85\left(\mathrm{~d}, 1 \mathrm{H}, \mathrm{H}-1^{\prime}, \mathrm{J}=0,8\right) ; 7,26-7,30(\mathrm{~m} \\
3 \mathrm{H}, \mathrm{Ph}) ; 11,59(\mathrm{~s}, 1 \mathrm{H}, \mathrm{NH})\end{array}$ & $212 ; 249,5 ;[280]^{*} ; 379$ \\
\hline
\end{tabular}

$\mathrm{N}$ o t e. UV spectra were recorded in ethanol; *concealed maximum; **compound yield by glycosilation method

Synthesis of 2- $\beta$-D-ribofuranosyl-3(4H)-oxo-7chloro-1,2,4-triazino[5,6-b][1,4]benzothiazine was performed similarly to $\mathbf{5 a}$ by the both methods. Yield of the target ribonucleoside by the method I made up $42.3 \mathrm{mg}$ (11\%), by the method II - $87.5 \mathrm{mg}$ (23\%) of analytically pure $\mathbf{5 b}$.

Transcription reaction in vitro. The technique for testing the synthesized substances on [a] model system of transcription was presented in previous report [13]. There were used such reagents: linearized DNA of pTZ19R plasmide as a template, four canonical ribonucleoside triphosphates, RNA inhibitor (RiboLock), transcription buffer (tris- $\mathrm{HCl}, \mathrm{pH} 7.5$, $\mathrm{MgCl}_{2}$, spermidine, dithiothreitol) of the firm "Fermentas" (Lithuania).

Test-agent pre-incubation with DNA-template or RNA-polymerase was conducted in the presence of other system components during $15 \mathrm{~min}$ at room temperature. Following pre-incubation the system was added with proper lacking biopolymer, and the reaction proceeded for $40 \mathrm{~min}$.

Results and discussion. Molecular modeling of condensed triazines. Through computer studies it was scheduled to solve such tasks: determine the topology and tautomere status of the 3-oxo-1,2,4-TBT parent base, accomplish the design by introducing the substituents of various structure and nature in triazine and benzothiazine fragments of molecule; elucidate behavior of the basic molecule and its derivatives in the model of T7 RNAP binding site; construct more active derivatives of the basic structure consistent with numerical trials.

Constructing the novel molecular structures suggests the invariance of the functional group position, donor-acceptor centers in triazine 1,2,4-TBT fragment, capable to interact with both matrix bases and conservative amino acid surrounding. Benzothiazine fragment being linked to triazine nucleus fills the extended cleft of polymerase catalytic site concurrently promoting realization of the numerous possibilities for stacking- and cation- $\pi$-interaction. To our mind substitution of the benzene nucleus may enhance the interaction of new derivatives with the enzyme at the expense of increase in their volume and hydrophobicity.

The presence of four nitrogen atoms and mobile protons results in tautomeric conversions of the basic compound and its derivatives. 


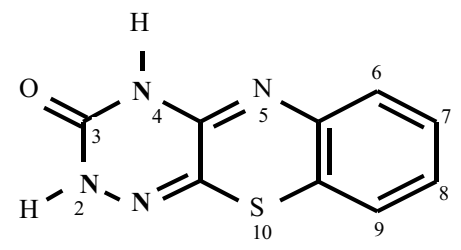

0

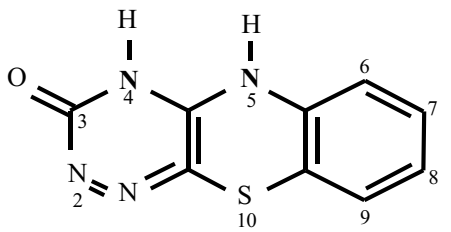

$b$

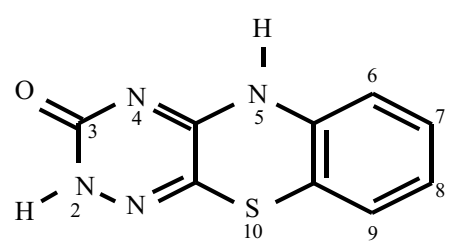

2,62

Fig. 1. The most possible tautomers $(\mathbf{a}-\mathbf{c})$ of 3-oxo-1,2,4-triazino[5,6-b][1,4]benzothiazine (4) and there relative Gibbs energy(Kcal/mol)

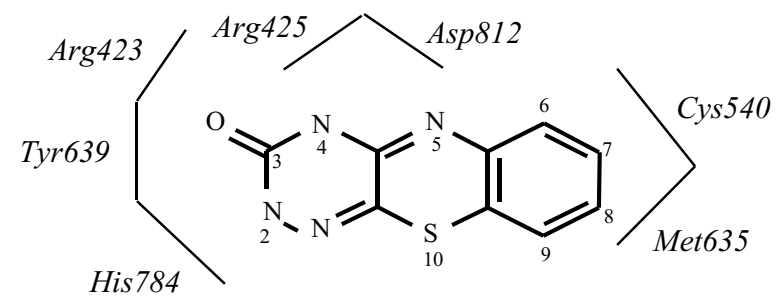

Fig. 2. Schematic representation of inhibitors binding site with marked key aminoacids residues

The first step of the computer studies was to determine more possible and energetically more advantageous tautomers of basic 3-oxo-1,2,4-TBT and their topology. Above characteristics may reflect in their behavior in the enzyme target and, hence, in the mechanism of action of these compounds, in other words, may affect their interaction with biopolymeres. The variations in energy of such interaction for a number of tautomers appeared to be insignificant while amino acid surrounding tended to be cardinally different, sometimes provoking emergence of so called "false positive hits". Optimization of the 3-oxo-1,2,4-TBT structure was accomplished by DFT.

The spatial structures of the most probable tautomers of basic compound were constructed by means of molecular design. Only one of three tautomers structures was close to planar, which appears to be energetically most favorable. According to spectral results exactly this tautomer was realized upon synthesis and used in docking to study the interaction between the compounds investigated and T7 RNAP active site. Fig.1 presents the structures of 3-oxo-1,2,4-TBT tautomers (4).

Further design of 3-oxo-1,2,4-TBT was aimed at enhancing the interaction of novel derivatives with the enzyme target and determining the putative mechanism of their interaction. To fill the volume of the enzyme complex pocket more densely the benzothiazine fragment was modified by introducing the haloid, haloidalkyl and alkyl groups in various positions.

While constructing the model of active site we considered all amino acid residues within the radius of $0.1 \mathrm{~nm}$ around the catalytic pocket as those that may be involved in ligand binding and those that ensure polymerase functioning (Fig. 2). It is important to define the enzyme dynamics during the catalytic event. It is necessary in order to avoid the appearance of the above mentioned "false positive hits", i.e. the compounds which should be active according to calculations but do not show any activity in biotestng. Through the docking in the chosen region of transcription complex in the model of T7 RNAP site there was carried out the virtual screening for modelled structures. The analysis of the obtained data revealed that ligands were situated for certain in the catalytic pocket and kept in it at the expense of hydrogen bonds, stacking- and cation- $\pi$-interaction with amino acid residues and matrix (template) nucleotide bases. The triazine fragment for most of considered structures is localized within immediate proximity to the catalytic $\mathrm{Mg}^{2+}$ ion and Tyr639 residue which takes part in recognition of the regular ribonucleoside triphosphate involved in the catalytic site. (Fig. 3, see pasting-in).

For derivatives with substitutes in the benzene ring two various models of binding proved to be acceptable. For the compounds with halogen-substitute or trifluoromethyl group at the $7^{\text {th }}$ position of benzene ring, the triazine cycle is fixed by stacking interaction with the matrix base (adenine) and hydrogen bonds with residues Asp812 and Arg425 ( the distance 
between respective atoms makes up 0.23 and $0.20 \mathrm{~nm}$ ) with substitutes establishing slight electrostatic bind with Lys441 (Fig. 4, see pasting-in).

There is other situation for 3-Oxo-1,2,4-TBT: the triazine fragment is kept in the active site owing to hydrogen bonds with residues Arg422 and Tyr427 (the distance between the atoms comprises 0.28 and 0.21 $\mathrm{nm}$, respectively), while benzothiazine one - due to hydrogen bonds with His784 residue (the distance between the proper atoms is $0.10 \mathrm{~nm}$ ). Alkyl strand seems to be plunged into the bulky pocket, formed by the Cys540 and Met635 residues (Fig. 5, see pasting-in) and fixed in it by the hydrophobic interactions. In such case the compound bonds with the matrix base within the complex are lacking, hence, its retention does occur only due to the interaction with enzyme.

Analysis of behaviour of the above mentioned bases' derivatives that carry glycoside residue in the triazine fragment in the model of catalytic site demonstrated the lack of unambiguous superposition upon identification of the most advantageous versions of their arrangement within the target. It should be emphasized that significant distinctions in the respective positions of the molecule in a virtual target may indicate a low energy of binding and as a result low inhibitory capacity of this substance despite the presence of five hydrogen bonds (Tyr639, His784, Asp812 Lys441, $\mathrm{Mg}^{2+}$ ) and minor distances between the atoms which form them $(0.16 ; 0.22 ; 0.29 ; 0.26$ and 0.25 , respectively).

The results of virtual screening allow us to suggest that the considered compounds may be potential inhibitors, the extended alkyl substitute of benzothiazine fragment being able to increase complex stability and in this way enhance their inhibitory activity. On the contrary, introduction of glycoside residue into the triazine fragment may result in an opposite effect.

Confirmation or rejection of this working hypothesis may come from testing the derived compounds' activity in the in vitro system of transcription catalysed by T7 RNAP.

In earlier studies we proposed rather simple scheme for the synthesis of tricyclic triazine-bearing system and its functionalization [3, 4]. Just this approach was extended to the synthesis of a number of new derivatives of basic 3-oxo-1,2,4-TBT Manufacturability and effectiveness are the positive attributes of the above method - the reaction occurs in unistage manner in the absence of specific conditions, thus allowing production in preparative quantities.

Such approach was used to obtain new triazine-bearing bases, substituted for chlorine atom or trifluoromethyl group at 7 or $n$-butyl substituent at 8 position of the benzothiazine fragment $(\mathbf{4 a}-\mathbf{c})$ and respective ribonucleosides $\mathbf{5 a}, \mathbf{5} \mathbf{b}$ with sugar moiety at position 2 of the triazine fragment.

The efficiency of synthesis appeared to be over 50 $\%$, reaching for $4 \mathbf{a} 67 \%, 4 \mathbf{b}-80 \%, 4 \mathbf{c}-53 \%$, but lower than that for non-substituted 3-oxo-1,2,4-TBT yielded up to $90 \%$. These data undoubtedly suggest the essential effect of the chemical nature of the substituents in the 2-aminobenzothiol molecule on the process of triazine-bearing heterosystem formation. As evidenced from Fig. 6, ribonucleosides $\mathbf{5 a}$ and $\mathbf{5 b}$ were obtained by two techniques to define which of them is more productive. In the case of triacetylriboside 5-bromo-6-azauracil (2) interaction with 2-aminobenzothiol 3a under above conditions (Fig. 6) the yield of the target product was $27 \%$, while upon using reagent $\mathbf{3 b}$ it is essentially less $-11 \%$ (compound 5b). Considerable decrease in the efficiency of synthesis of the ribofuranosides by this method may be ascribed first of all to acylnucleoside susceptibility (2) to the reaction conditions (temperature over $100^{\circ} \mathrm{C}$ ), and, like upon bases synthesis, to rather considerable influence of $\mathrm{Cl}$ - and $\mathrm{CF}_{3}$-substitutes of corresponding 2-aminobenzothiols.

Direct glycosylation of the triazine-bearing bases $(\mathbf{4 a}, \mathbf{4 b})$ by the described procedure [3] somewhat increased a yield of the final product for [the] $\mathrm{CF}_{3}$-substituted [basis] (33\%) and significantly raised outcome for the Cl-substituted base (23\%). Negative contribution to the glycosylation process and obtainng nucleoside of needed structure is determined by the presence of at least two reaction centres (nitrogen atoms in positions 2 and 4), i.e there is a possibility of formation of two isomeric products. Analysis of the reaction mixture showed that total yield of acylated glycosides was about $60 \%$, but the proportion of acetate of the prevailing $2-\mathrm{N}$-nucleoside did not exceed $45 \%$. Free ribofuranosides $\mathbf{5 a}, \mathbf{5 b}$ were derived by 


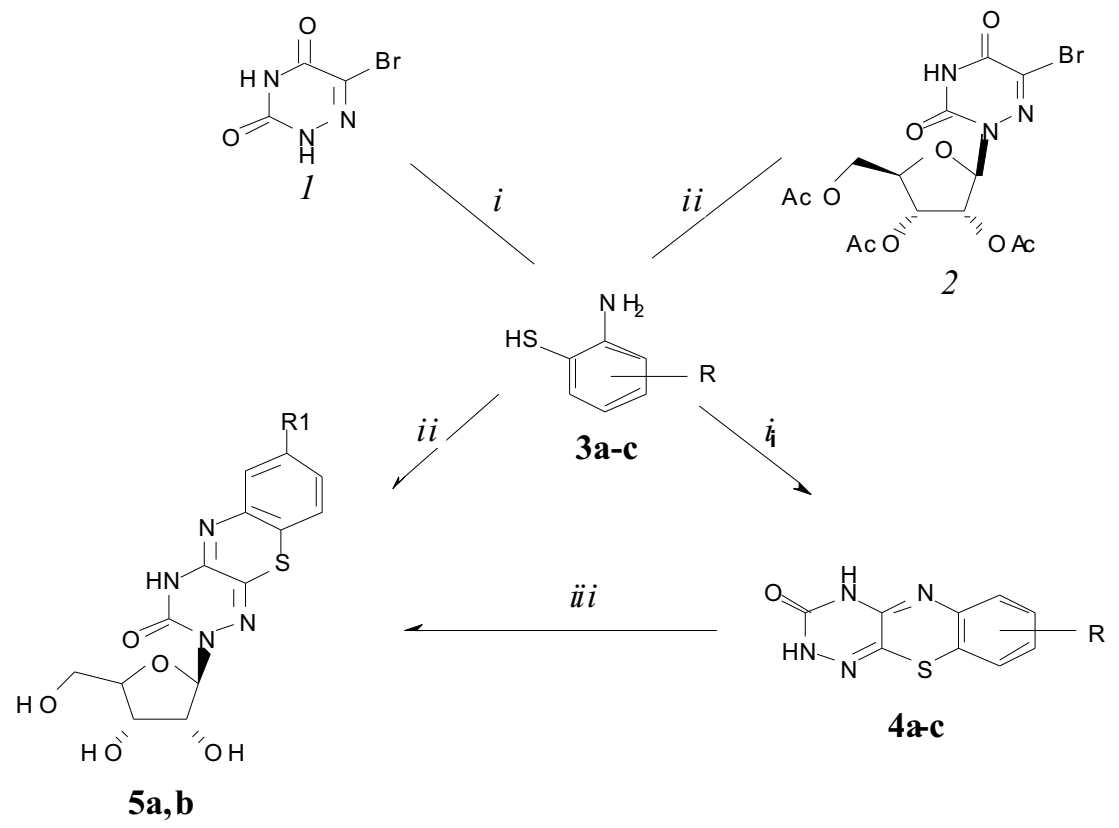

where $\mathrm{R}=\mathrm{R}_{1}=\mathrm{H}(\mathbf{4}, \mathbf{5}) ; \mathrm{R}=\mathrm{R}_{1}=\mathrm{CF}_{3}(\mathbf{a}) ; \mathrm{R}=\mathrm{R}_{1}=\mathrm{Cl}(\mathbf{b}) ; \mathrm{R}=\mathrm{n}-\mathrm{Bu}(\mathbf{c})$.

Rea gent $\mathrm{s}$ andreaction condit ions $i$ ) $1-\mathrm{EOH}-\mathrm{DMFA}, \mathrm{Py}, 120^{\circ} \mathrm{C} ; 2-\mathrm{NH}_{4} \mathrm{OH} / \mathrm{HOH}, 20^{\circ} \mathrm{C}$; i )

di ox an e-Py, $100^{\circ} \mathrm{C}$; iii i) 1 -acet oni trile, tetraacetylribo se, TMCS, $\mathrm{HMDS}, \mathrm{SnCl}_{4}, 25^{\circ} \mathrm{C} ; 2$ -

$\mathrm{NH}_{4} \mathrm{OH} / \mathrm{HOH}, 20^{\circ} \mathrm{C}$

Fig. 6. Scheme of 7(8)R-3-oxo1,2,4-triazino[5,6-b][1,4]benzothiazine synthesis deacetylation of corresponding acetates with aqua-alcohol solution of ammonium hydroxide.

The comparison of tricyclic ribonucleosides preparations, obtained in alternative ways, showed their identity.

Investigation of the regulatory properties of the obtained compounds in the model transcription complex in vitro. The primary base (4) and its ribofuranoside derivative (5) as compounds for comparison, the synthesized bases $(\mathbf{4 a}-\mathbf{c})$ and two ribonucleosides (5a, 5b) were tested in the enzyme system. The concentration- and structure-dependent inhibition of total RNA synthesis by the 1.2.4-TBT derivatives was observed in the model system of T7 RNAP transcription in vitro. Contrary to the initial base $\mathbf{4}$, RNA synthesis was reliably suppressed by three bases - with $\mathrm{C} 1-, \mathrm{CF}_{3}$ and $n$-butyl- substitutes in the benzothiazine fragment of compounds $\mathbf{4 a}, \mathbf{4 b}$ and $\mathbf{4 c}$ (Fig. 7). The $n$-butyl derivative 4c proved to be the most effective inhibitor of the transcription process in vitro among the compounds under study as was predicted by the docking results. Practically complete absence of the transcript was found at $\mathbf{4 c}$ concentration of $6 \mu \mathrm{g} / \mathrm{ml}$.
Our hypothesis concerning glycoside derivatives $\mathbf{5 a}$ and $\mathbf{5 b}$ was also affirmed. Their testing in "living" enzyme system did not reveal any inhibition of RNA synthesis as compared with the corresponding bases, i.e. these ribonucleosides $(\mathbf{5 a}, \mathbf{5 b})$ appeared to be "erroneously found hits" as was predicted by the results of docking.

To establish to which of two biopolymers, DNA and T7 RNAP, the 1.2.4-TBT derivatives possess higher affinity the compounds were pre-incubated with each of them. As is exemplified from butyl $\mathbf{4 c}$ derivative, the pre-incubation with T7 RNAP practically did not change the course of concentration-dependent transcription reaction, as compared with the standard conditions, but almost half reduced the minimal inhibiting concentration of this substance (Fig. 8). Instead, pre-incubation of $\mathbf{4 c}$ with DNA considerably affects the course of concentration-dependent RNA synthesis. The substance distribution along the template seems to reduce substantially the inhibitor working concentration and as a result RNA transcript appears at its higher concentrations (starting from $25 \mu \mathrm{g} / \mathrm{ml}$ ). 

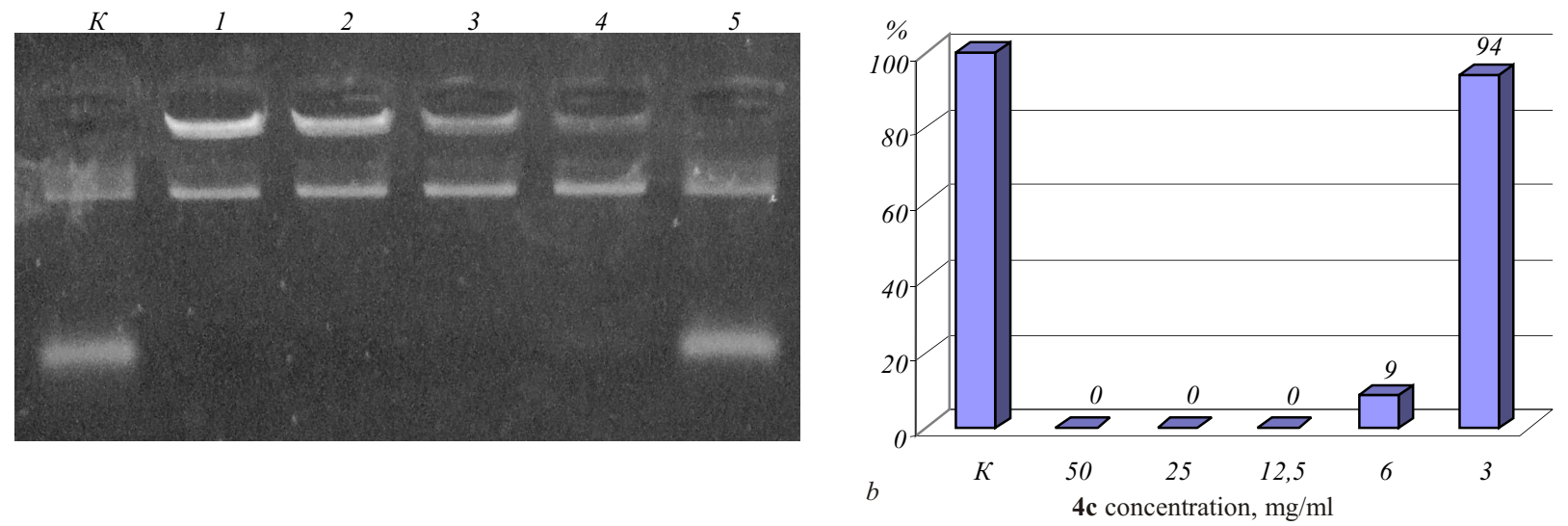

Fig. 7. RNA synthesis inhibition in vitro (T7 RNAP transcription) by compound $\mathbf{4 c}$ under standard conditions. The total inhibition was determined by absence of RNA transcripts in agarose gel: $a$-typical electroforegramm of RNA transcripts from three different experiments $(K$ - positive control; $1-50 ; 2-25 ; 3-12,5 ; 4-6 ; 5-3 \mu \mathrm{g} / \mathrm{ml} \mathrm{4c}) ; b$ - average results, presented as a percent of RNA transcript from positive control $(K)$ (Scion program)
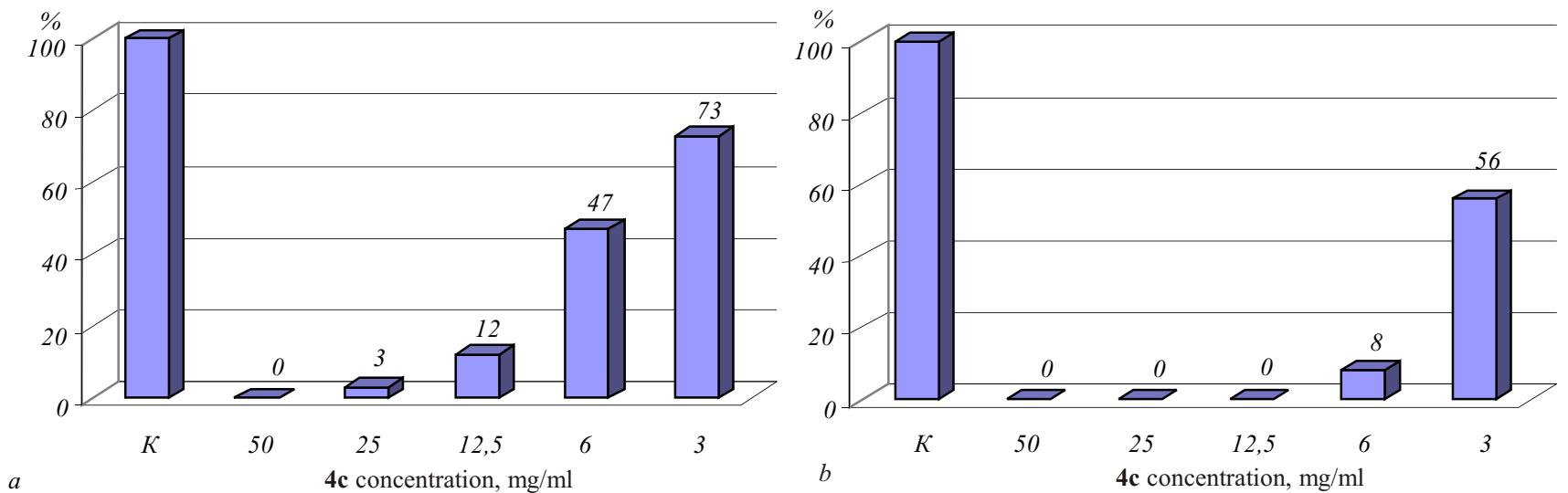

Fig. 8. Influence of pre-incubation ( $15 \mathrm{~min}$, at room temperature) of $\mathbf{4 c}$ with DNA-template $(a)$ or T7 RNAP (b) on RNA synthesis suppression in vitro (T7 RNAP transcription). Average results presented as a percent of RNA transcript from positive control ( $K$ ) (Scion program)

Probably, interaction of the compound $\mathbf{4 c}$ with $\mathrm{T} 7$ RNAP is critical in RNA synthesis suppression.

Conclusions.

1) $\mathrm{A}$ series of new

\section{1,2,4-triazino[5,6-b][1,4]benzothiazine derivatives} was desihned by the methods of computational biology.

2) The compounds of predicted structure with lateral substituents in positions 2, 7 and 8 in 3-oxo-1,2,4-triazino[5,6-b][1,4]benzothiazine were synthesized using technologically advantageous methods, among them 2-N-ribonucleosides with $\mathrm{CF}_{3}$ group or chlorine atom in the benzene ring; the identity of the glycoside derivatives obtained by two independent methods was verified.

3) Rather effective inhibitors of RNA synthesis were identified by testing the synthesized substances in T7 RNAP transcription system in vitro. Analysis of the results allowed us to suggest that the compounds studied are able to interact with both biopolymers, the enzyme and DNA. According to the biological test, 3-oxo-8- $n$-butyl-triazinobenzothiazine appeared to be 
the most effective inhibitor; to our mind, a critical role in this effect belongs to its interaction with both free RNA-polymerase molecules and those inside the transcription complex.

Л. Г. Пальчиковська, І. В. Алексєєва, М. О. Платонов, О. М. Костенко, Л. С. Усенко, В. В. Негруиька, А. Д. Швед

Нові сполуки конденсованого 1,2,4-триазину: молекулярне моделювання, синтез та біотестування

Резюме

Мета. Розширити спектр біологічно активних сполук 1,2,4-триазино[5, 6-b] [1,4]бензотіазинів (1,2,4-ТБТ) та виявити з-поміж них інгібітори синтезу РНК. Методи. Неемпірична квантово-хімічна оптимізація структури 3-оксо-1,2,4-ТБТ фрагментно-орієнтованим заміщенням, їхній молекулярний докінг у віртуальну мішень, раціональний хімічний синтез теоретично спрогнозованих речовин та їхнє тестування у модельній ферментативній системі транскрипції. Результати. Отримано низку похідних 1,2,4-ТБТ із замісниками у бензольному і триазиновому ииклах базової молекули. Тестування сполук у системі транскрипиї іп vitro ДНК-залежною РНК-полімеразою бактеріофага $T 7$ визначило структурно- та концентраційно-залежне пригнічення ними синтезу РНК. Для всіх досліджуваних сполук експериментальні дані задовільно корелюють з результатами віртуального скринінгу. Найефективнішим інгібітором виявився 3-оксо-8-бутил-1,2,4- ТБТ, який у концентрації 6 мкг/мл забезпечує повне блокування транскрипиії. Висновки. Аналіз даних тестування дозволяє припустити, щзо пригнічення синтезу РНК обумовлено зв'язуванням 3-оксо-8-бутил-1,2,4-ТБТ як з неасочійованою РНК-полімеразою, так $i$ з РНК-полімеразою у складі транскрипиійного комплексу.

Ключові слова: 1,2,4-триазино[5,6-b][1,4]-бензотіазини, комп'ютерне моделювання, віртуальний скринінг, синтез, модельна система транскрипиії.

Л. И. Пальчиковская, И. В. Алексеева, М. О. Платонов, А. Н. Костенко, Л. С.Усенко, В. В. Негруикая, А. Д. Швед

Новые соединения конденсированного 1,2,4-триазина: молекулярное моделирование, синтез и биотестирование

Резюме

Цель. Расширить спектр биологически активных соединений в ряду производных 1,2,4-триазино[5,6-b] [1,4]бензотиазина (1, 2,4-ТБТ) и выявить среди них ингибиторы синтеза РНК. Методы. Неэмпирическая, квантово-химическая оптимизация структуры 3-оксо-1,2,4-ТБТ фрагментно-ориентированным замещением, молекулярный докинг новых структур в виртуальную мишень, рациональный химический синтез теоретически спрогнозированных веществ $и$ их тестирование в модельной ферментативной системе транскрипиии. Результаты. Получена серия производных 1,2,4-ТБТ с заместителями в бензольном и триазиновом ичиклах базовой молекуль.
Тестирование веществ в системе транскрипщии in vitro ДНКзависимой РНК-полимеразой бактериофага T7 определило структурно- и концентрационно-зависимое ингибирование синтеза РНК. Для всех исследованных соединений экспериментальные данные удотвлетворительно коррелируют с результатами виртуального скрининга. Наиболее эффективным ингибитором оказался 3-оксо-8-бутил-1,2,4-ТБТ, который в концентрации 6 мкг/мл обеспечивает полное блокирование транскрипции. Выводы. Анализ данных тестирования позволяет предположить, что угнетение синтеза РНК обусловлено связыванием 3-оксо-8-бутил-1,2,4-ТБТ как с неассоциированной РНК-полимеразой, так и с РНК-полимеразой в составе транскрипиионного комплекса.

Ключевые слова: 1,2,4-триазино [5,6-b] [1,4]бензотиазины, компьютерное моделирование, виртуальный скрининг, синтез, модельная система транскрипиии.

\section{REFERENCES}

1. DNA and RNA binders. From small molecules to drugs / Eds M. Demeunynck, C. Bailly, W. D. Wilson.-Weinheim: Wiley-VCH, 2003.-Vol. 1.-P. 278-315.

2. Hendry L. B., Mahesh V. B., Bransome Jr. E. D., Ewing D. E. Small molecule intercalation with double stranded DNA: Implications for normal gene regulation and for predicting the biological efficacy and genotoxicity of drugs and other chemicals // Mutat. Res.-2007.-623.-P. 53-71.

3. Alexeeva I. V., Palchikovskaya L. G., Rybalko S. L., Usenko L. S., Kobko O. S., Popova L. A., Dyadun S. T., Shved A. D. Nucleosides with tricyclic aglycone. The ribonucleosides of condensed 1,2,4-triazine: synthesis and its antiherpetic activity // Biopolymers and Cell.-2006.-22, N 6.-P. 468474.

4. Alexeeva I. V., Palchikovska L. G., Usenko L. S., Kostina V. $G$. Tricyclic 1,2,4-triazine bearing heterosystem: directed synthesis of new bioactive compounds // Biopolymers and Cell.-2008.-24, N 5.-P. 406-411.

5. Nagamatsu T., Yamasaki H., Hirota T., Yamato M., Kido Y., Shibata M., Yoneda F. Syntheses of 3-substituted 1-methyl6-phenylpyrimido[5,4-e]-1,2,4-triazine-5,7(1H, 6H)-diones (6-phenyl analogs of toxoflavin) and their 4-oxides, and evaluation of antimicrobial activity of toxoflavins and their analogs // Chem. Pharm. Bull. (Tokyo).-1993.-41, N 2.-P. 362368.

6. Shorshnev S. V., Yesipov S. Ye., Chernyshev A. I., Pozharskii A. F., Nanavyan I. M., Kuz'menko V.V. Different basic hydrolysis of fervenuline and isofervenuline // Chem. Heterocycl. Compounds (Russia).-1987.-N 11.-P. 1555-1559.

7. Piestrzeniewich M., Studzian K., Wilmanska D., Plucienniczak G., Gniazdowski M. Effect of DNA-interacting drugs on page T7 RNA polymerase // Acta Biochim. Pol.-1998.-45, N 1.- P. 127-132.

8. McMartin C., Bohacek R. S. QXP: powerful, rapid computer algorithms for structure-based drug design // Comput. Aided Mol. Des.-1997.-11, N 4.-P. 333-344.

9. Temiakov D., Patlan V., Anikin M., Callister W. T., Yokoyama $S$., Vassylyev D. G. Structural basis for substrate selection by T7 RNA polymerase // Cell.-2004.-116, N 3.-P. 381-391.

10. Warren G. L., Andrews C. W., Capelli A. M., Clarke B., LaLonde J., Lambert M. H., Lindvall M., Nevins N., Semus S. F., Senger S., Tedesco G., Wall I. D., Woolven J. M., Peishoff C. 
E., Head M. S. A critical assessment of docking programs and scoring functions // J. Med. Chem.-2006.-49, N 20.P. 5912-5931.

11. Alexeeva I. V., Palchikovs'ka L. G., Usenko L. S., Kostina V. G. 5-Aminosubstituted triazine nucleosides and their furanidylic analogues: synthesis and primary screening on tumor cell models // Biopolymers and Cell.-2005.-21, N 2.-P. 174179.

12. Thomas L., Gupta A., Gupta V. Synthesis of 2-amino-5-cloro3(trifluoromethyl)benzenethiol and conversion into 4H-1,4benzothiazines and their sulfones // J. Fluorine Chem.2003.-122, N 2.-P. 207-213.
13. Palchykovska L. G., Alexeeva I. V., Kostina V. G., Platonov M. O., Negrutska V. V., Deriabin O. M., Tarasov O. A., Shved $A$. D. New amides of phenazine-1-carboxylic acid: antimicrobial activity and structure-activity relationship // Ukr. Biochem. J.-2008.-80, N 3.-P. 140-147.

14. Levine M., Tjian $R$. Transcription regulation and animal diversity // Nature.-2003.-424, N 6945.-P. 147-151.

UDC 547.836:573.3:577.15.04 Received 10.07.09 
Figure to article by Palchykovska L. G. et al.



Fig. 3. Localization of 7-trifluoromethyl-3-oxotriazinobenzothiazin in the model of T7 RNAP active site (data of molecular doking)



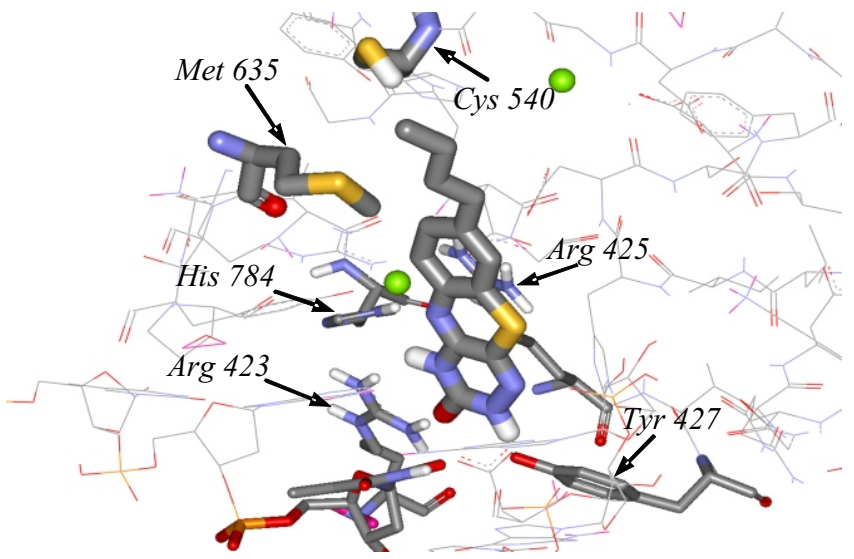

Fig. 4. Localization of 8-butyl-3-oxo-triazinobenzothiazin in the model of T7 RNAP active site (method of molecular doking)

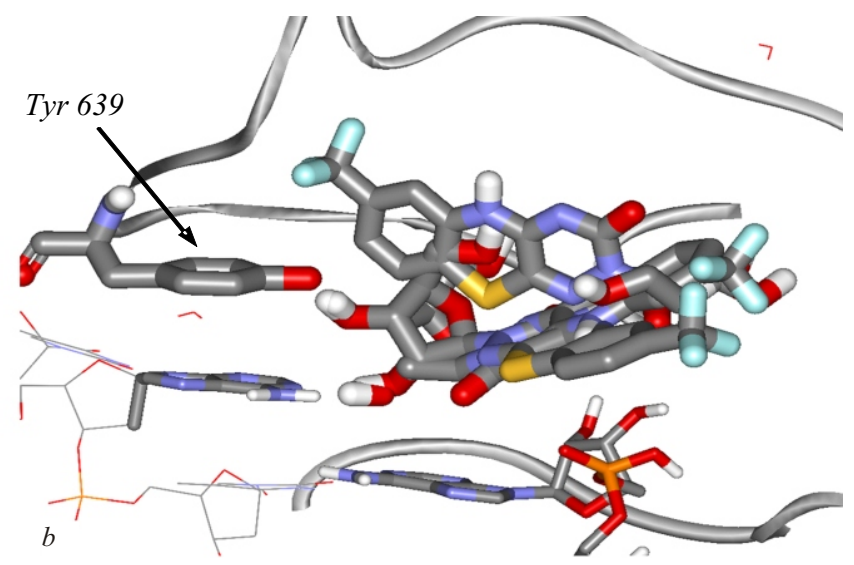

8-butyl-3-oxo-1,2,4-triazinobenzothiazin (a) and 